HID 45 (2018)

\title{
LA APORTACIÓN ECLESIÁSTICA A LAS RENTAS DE LA CORONA: SUBSIDIO Y EXCUSADO EN EL ARZOBISPADO DE SEVILLA DURANTE EL REINADO DE FELIPE II ${ }^{1}$
}

\author{
THE ECCLESIASTICAL CONTRIBUTION TO THE ROYAL \\ TREASURE: SUBSIDY AND EXCUSADO IN THE SEVILLE'S \\ ARCHBISHOPRIC DURING THE REIGN OF PHILIP II
}

\author{
GEMA RAYO MUÑOZ \\ Universidad de Granada \\ gemarayo@hotmail.com ORCID: https://orcid.org/0000-0002-7228-8467
}

RESUMEN: En este trabajo abordaremos dos contribuciones eclesiásticas, subsidio de galeras y excusado, en el arzobispado de Sevilla durante el reinado de Felipe II. Ambos impuestos comenzaron a cobrarse con Felipe II, institucionalizando así una larga tradición de exacciones eclesiásticas por parte del Estado, que habían comenzado durante la Baja Edad Media y que culminaría prácticamente con la caída del Antiguo Régimen. Nuestro propósito en este artículo será ver para el caso del arzobispado de Sevilla, el segundo más rico después de la Sede Primada, cómo se fijaba esta contribución económica, cómo se repartía la carga fiscal entre los distintos miembros del clero, cómo se llevaba a la práctica dicha recaudación, qué agentes fiscales intervenían en ella y qué deudas pagó efectivamente la Hacienda Real gracias a la percepción de ambas rentas eclesiásticas.

PAlabras ClaVe: Subsidio; excusado; fiscalidad; arzobispado de Sevilla; Felipe II.

Recibido: 13-3-2018; Aceptado: 18-6-2018; Versión Definitiva: 9-8-2018.

1. Una versión preliminar de este estudio fue presentado como trabajo fin de máster en la Universidad de Sevilla, que obtuvo Matrícula de Honor. Agradecer al tutor del mismo, el profesor José Antonio Ollero Pina, su inestimable ayuda tanto en el proceso de documentación en el archivo como sus sugerencias y correcciones durante la redacción. Asimismo dar las gracias al profesor Ángel Galán Sánchez, de la Universidad de Málaga, por su supervisión y consejos. El presente artículo se encuadra dentro del proyecto del MINECO "Poder, fiscalidad y sociedades fronterizas en la Corona de Castilla al sur del Tajo (siglos XIV-XV) (HAR2014-52469-C3-1-P). Abreviaturas utilizadas: ACS = Archivo Catedralicio de Sevilla; AGI = Archivo General de Indias; FHG = Fondo Histórico General.

2. Contratada FPU del MECD 14/03501 en la Universidad de Granada.

Copyright: (C) Editorial Universidad de Sevilla. Este es un artículo de acceso abierto distribuido bajo los términos de la licencia de uso y distribución Creative Commons Reconocimiento-No-ComercialSinObraDerivada 4.0 (CC BY-NC-ND 4.0) 
ABSTRACT: In this essay, we will research about the ecclesiastical contributions, specifically subsidy and excusado, in the Seville's Archbishopric during the reign of Philip II. Both taxes began to collect with Philip II, consolidating a large tradition of ecclesiastical levies belonging to the State, which had started during the Middle Ages and finished with the fall of the Ancien Regime. Our purpose in this article will be to expose how the Seville's Archbishopric established that economic contribution, what was the tax burden, how was carried out the collection, who agents participated in the process and what debts paid the Crown due to these taxes.

KEYWORDS: Subsidy; Excusado; taxation; Seville’s Archbishopric; Philip II.

\section{INTRODUCCIÓN}

En este trabajo nos hemos propuesto hacer una humilde aportación sobre dos de los recursos eclesiásticos más importantes percibidos por el Rey Prudente -subsidio de galeras y excusado-, centrándonos en el arzobispado de Sevilla. La decisión de focalizar nuestra investigación en el arzobispado hispalense viene determinada por ser, con casi toda probabilidad, la segunda iglesia peninsular más rica después de Toledo para el periodo que aquí nos ocupa ${ }^{3}$. Junto a esto, también se han tenido en cuenta otros elementos, como la inexistencia de estudios similares previos y la accesibilidad de las fuentes conservadas en el Archivo Catedralicio de Sevilla.

Entre los siglos XIII y XVI se otorgaron varios subsidios o décimas con finalidades muy concretas, como la financiación de una campaña o empresa militar. Si estas concesiones se afianzaron durante el reinado de los Reyes Católicos y del emperador Carlos V, fue sin embargo con Felipe II cuando se institucionalizaron definitivamente, con una consiguiente transformación de la conciencia fiscal. Tras un primer intento, considerado como infructuoso por Felipe II por no satisfacer sus aspiraciones, en 1563 Pío IV promulgaría la bula "Ad Romani Pontificis", gracias a la cual la Hacienda Real se ingresaría 420.000 ducados quinquenio destinados teóricamente a construir y mantener una escuadra de 60 galeras $^{4}$, a las que el rey tendría que sumar adicionalmente otras 40 por su cuenta y riesgo. Poco después Pío $\mathrm{V}$, en paralelo a su intento de crear un único espacio físcal italiano, hegemonizado por la Hacienda de los Estados Pontificios ${ }^{5}$, dispensó a Felipe II un nuevo tributo sobre las rentas eclesiásticas: el excusado. La primera bula papal fue la de

3. Aun así, pese a existir un cierto consenso sobre esta afirmación, conviene advertir de la dificultad de calcular las rentas de las mitras, cabildos y fábricas porque las iglesias remitían sus cifras a la Cámara de Castilla por trienios o quinquenios. Además, hay que tener en cuenta otros factores como la ocultación, que provocaba que el valor de los diezmos tirase hacia la baja. Vid. Domínguez Ortiz., 1991, p. 174.

4. Cloulas 1967, p. 298.

5. En esta línea podía encuadrarse la petición de Pío V al monarca español para que rehusase a cobrar la décima en sus dominios italianos. Vid Visceglia 2004, p. 173. 
“Circa pastoralis officii”, del 15 de julio de 1567, por la cual se le concedía a la Corona la tercera casa dezmera más rica de cada parroquia ${ }^{6}$. Aunque el rey, de aceptar esta nueva Gracia, hubiese podido empezar a cobrar sus frutos en 1568, decidió esperar y recurrir a la negociación para alcanzar un acuerdo más provechoso. La financiación de la Liga Santa y el inminente enfrentamiento con los otomanos, hicieron que finalmente el papa decidiese otorgarle en 1571 por mediación de su bula "Sane alias" la primera casa dezmera de cada parroquia.

Hasta hace relativamente poco tiempo la historiografía de nuestro país no prestó un excesivo interés hacia esta problemática, salvo honrosas excepciones que abordaban la suerte de dichas rentas desde un panorama hacendístico general ${ }^{7}$. Más allá de los datos cuantitativos, tras la fiscalidad existe un trasfondo de lucha por la hegemonía y de transformación institucional del aparato político, conducente a eso que llamamos Estado Moderno y Monarquía Autoritaria, conceptos que pueden ser más o menos equívocos pero que expresan al menos un cambio de paradigma del modelo europeo. Ahora bien, estas correlaciones de fuerza entre ambos poderes, el regio y el eclesiástico, pueden exhibirse desde múltiples perspectivas, siendo las congregaciones del clero una de ellas ${ }^{8}$. Sin embargo han sido muy pocos los estudios centrados en conocer, al menos parcialmente, algunos aspectos relevantes del subsidio de galeras y del excusado durante el reinado de Felipe II, como su prorrateo, recaudación, los agentes fiscales que en él intervienen o el destino de las contribuciones ${ }^{9}$, y esto, extendiéndolo a la iglesia de Sevilla resulta novedoso ${ }^{10}$. Por ello, la casi absoluta ausencia de estudios que aborden ambas rentas desde una perspectiva global -partiendo desde el momento en que la congregación del clero asigna la cuantía a una determinada iglesia hasta que ésta libra el dinero en manos de su destinatario- lo hace hasta cierto punto necesario. Aun así, conviene señalar en todo momento que los resultados e interpretaciones aquí expuestas son en parte provisionales, debido especialmente al exclusivo carácter eclesiástico de las fuentes consultadas. Para ampliar el campo de estudio y validar algunas de las hipótesis planteadas, sería necesario un estudio sistemático de la documentación conservada en el Archivo General de Simancas y en el Archivio Segreto Vaticano. No obstante, esperemos que sirva como punto de partida de cara a futuras investigaciones.

6. Aldea, 1972, p. 713.

7. A este respecto no podemos menos que citar Ladero Quesada, 2009; Carande Thovar, 1949; Ulloa, 1986.

8. En las relaciones entre Iglesia y Monarquía en la Baja Edad Media cabría destacar algunos de los trabajos de Nieto Soria 1993; 1994, pp. 113-132; 1999, pp. 19-48. En cuanto a las congregaciones del clero, son de obligada referencia los estudios de Tarsicio de Azcona, 1983, y la tesis de Carpintero Aguado, 1993. Asimismo, hemos de añadir el ensayo de Perrone, 2008, centrado en época del emperador Carlos V.

9. Hasta donde sabemos, los únicos trabajos que abordan algo semejante son los dos de Catalán Martínez 1991, pp. 41-58 y 2013, pp. 345-377; y Álvarez Vázquez 1990. pp. 123-137.

10. Los únicos artículos publicados hasta el momento son de instantes previos o posteriores al periodo analizado. Vid. Ollero Pina 2011, pp. 115-131; Hernández Borreguero 2007, pp. 80-99. 


\section{LA CONTRIBUCIÓN DEL CLERO HISPALENSE}

\subsection{La distribución de la presión físcal entre las iglesias castellanas}

Cuando Pío IV otorgó el subsidio de galeras a Felipe II en 1563, la bula de concesión instaba a los comisarios y ejecutores del subsidio a cargar el nuevo impuesto de forma proporcional sobre las rentas eclesiásticas, lo que se traducía en una modificación de las anteriores cuotas de reparto. Tras varias discusiones, la congregación del clero decidió tomar como base la averiguación de veros valores de 1551, pero corrigiendo sus posibles desequilibrios ${ }^{11}$. En virtud de esto se decidió, por un lado, reducir la presión fiscal de las iglesias castellanas en detrimento de otras pertenecientes al Reino de Aragón, Granada o las Islas Canarias y, por el otro, corregir las desigualdades existentes entre las propias iglesias castellanas. Este nuevo repartimiento perjudicaría sobre todo a Toledo y Sevilla, mientras que Oviedo, León, Burgos, Calahorra y La Calzada, entre otras, se verían beneficiadas. En el caso de Sevilla, su contribución se vio incrementada en 262.000 maravedíes anuales $^{12}$. La nueva distribución se mantendría hasta 1615 , por lo cual permanece durante todo el periodo contemplado en este estudio.

Hasta aquí lo que afectaba al subsidio de galeras. Ahora bien, cuando Pío V concedió al Rey Prudente el excusado, la conflictividad en torno a su reparto fue aún mayor si cabe. Aunque la congregación del clero de 1572 pidió la revocación de esta gracia, la consecuente negativa monárquica les llevó a buscar unas condiciones más favorables para sus intereses, que no eran los mismos en todas las diócesis. En el caso de Sevilla, sólo diez días después de la publicación de las instrucciones para seleccionar a los primeros dezmeros de las parroquias, el clérigo Andrés de León presentó, apoderado por el deán y cabildo de la iglesia Sevilla, un escrito de suplicación contra la nueva contribución. En él exponía dos problemas específicos que afectaban al Arzobispado de Sevilla. Por una parte, los arrendadores, aguardando la publicación de los primeros dezmeros de las parroquias, no estaban pujando por los otros diezmos o hacían su oferta muy a la baja, por temor a que tuviesen un escaso valor. Por otra parte, una comisión apostólica había adjudicado en muchos lugares los primeros dezmeros al prelado y a los beneficiados, mientras que los segundos dezmeros quedaban reservados a las fábricas de las parroquias $^{13}$. Si, como se señalaba en otro documento suscrito por la misma fecha, la fábrica de la iglesia pasaba de recibir el segundo dezmero a quedarse con el tercero, la Corona quedaba advertida de que "no podrá acabarse el templo della, ni los demás edificios que están empezados, especialmente la Capilla Real, que es tan costosa"14.

Después de una larga negociación, la congregación del clero y el monarca alcanzaron un acuerdo a finales de 1572, refrendado poco después por el papa

11. Carpintero Aguado 1993, p. 91.

12. Véase Iturrioz Magaña 1987, pp. 32-33, y Carpintero Aguado 1993, p. 92.

13. ACS, FHG, Caja 111, 1, f. 360-362.

14. ACS, FHG, Caja 111, 1, f.310. 
Gregorio XIII, que modificaba la propia naturaleza del excusado y favorecía a los intereses defendidos por la mayoría del clero. En lugar de percibirse la primera casa dezmera de cada parroquia, se estableció una cantidad alzada sobre las rentas eclesiásticas, lo que suponía una contribución fija de 1.250.000 ducados cada quinquenio, a razón de 250.000 ducados anuales ${ }^{15}$. La derrama de esta suma entre las distintas iglesias de la Corona de Castilla, incluyendo además a la de Orihuela, se hizo tomando como referencia los valores y el repartimiento fijado en 1565 para el subsidio, de manera que la distribución de la presión fiscal era exactamente la misma que en el caso del subsidio de galeras. De cara a los intereses eclesiásticos, uno de los aspectos positivos de este acuerdo pasaba por que la Monarquía continuase desconociendo lo que rentaban los principales dezmeros de cada una de las sedes.

No obstante, queda claro que algunas iglesias como la sevillana hubiesen preferido que se llevase a cabo una nueva tasación de veros valores exclusiva para el excusado, ya que les perjudicaba que la de 1565 tomara como base el total de las rentas eclesiásticas y no únicamente las decimales. Así, en una carta dirigida por el deán del cabildo sevillano a Juan Bautista de Montoya, su representante en la congregación del clero de 1577 , le colegía que el valor anual de todas las rentas del arzobispado era de 235.150.000 mrs, mientras que el valor de todas sus rentas decimales era de 121.870.000 mrs. De ahí que la iglesia de Sevilla se opusiese siempre a que el excusado se tomase sobre todas las rentas y propiedades eclesiásticas, y no exclusivamente en base a los diezmos, lo cual sí beneficiaba a otras iglesias. Cinco años más tarde, en 1582, vemos al procurador hispalense Pedro de Cartagena quejándose ante la asamblea del clero de que mientras que en el resto de Castilla el dinero ofrecido por los arrendadores era superior a la suma ofrecida al monarca en el tanto alzado, en Sevilla los licitadores habían pujado por debajo de esta cantidad, y eso que se les había ofrecido una serie de ventajas como la facultad de sacar el trigo por tierra y mar $^{16}$.

Sin embargo, ni estas ni otras quejas lograron modificar el repartimiento acordado en 1565. La vez que más cerca se estuvo de lograrlo fue en 1591, año en que se intentó poner en marcha un proyecto ambicioso que tasara los frutos, las rentas y beneficios de todas las iglesias, atendiendo a su vez a todas las fluctuaciones sufridas durante este tiempo. Pero los costes, la inexactitud de las oscilaciones de rentas y, sobre todo, el riesgo que corrían las iglesias desvelando sus riquezas, provocaron que nunca se llevara a cabo ${ }^{17}$.

\subsection{El reparto del subsidio entre el clero del Arzobispado de Sevilla}

Una vez visto en base a qué criterios las congregaciones del clero asignaban las cuantías que cada sede debía de aportar en concepto de subsidio y de excusado, queda por conocer cómo se llevaba a cabo el reparto interno dentro de una

15. Ulloa 1986, p. 625.

16. ACS, FHG, Caja 111, f. 193 rv.

17. Carpintero Aguado 1993, p. 119. 
determinada iglesia. Antes de ofrecer cualquier resultado, queremos señalar la práctica ausencia de trabajos que hayan abordado previamente esto para Castilla. Nuestras hipótesis no son ni mucho menos definitivas, puesto que nos ha sido posible examinar sistemáticamente toda la documentación conservada en el catedralicio y hemos realizado únicamente un rastreo de determinados años. Aun así, podemos hacer una aportación acerca de los mecanismos de tributación de esta renta.

En primer lugar, conviene aclarar que si bien la cantidad que debía de aportar cada una de las iglesias permaneció invariable desde 1565 hasta 1615, hubo reajustes dentro de los propios arzobispados que varió la presión fiscal sobre cada uno de los contribuyentes (repartimiento al por menor). En el caso de Sevilla hubo, para el periodo cronológico que nosotros abordamos, dos averiguaciones de veros valores, una en 1565 y la otra en 1588, que actualizaron los valores de las rentas beneficiales.

La estructura tanto de los libros de subsidio como de los de excusado responde a una misma tipología, con tres columnas que ofrecen la siguiente información: cuerpo eclesiástico a gravar, lo que valen las rentas de sus beneficios anuales y lo que les corresponde pagar. Estos cálculos se realizaban en función de las tasaciones de 1565 y 1588, que vimos con anterioridad. En primer lugar, aparece la Mesa Arzobispal, la Mesa Capitular y la Fábrica, seguido por el resto de miembros que componen el cuerpo catedralicio. A continuación, están las collaciones de la ciudad de Sevilla, las vicarías de su término y algunos pocos abades y priores. La participación de rentas eclesiásticas en manos de seglares se extralimita a tercias señoriales y a propietarios de juros en las tercias del pan. Por último, se encontrarían los monasterios, cofradías y hospitales ${ }^{18}$.

De los libros estudiados del $1^{\circ}$ y del $3^{\circ}$ quinquenio del subsidio de galeras podemos determinar que éste suponía en torno al $5 \%$ de las rentas anuales de cada beneficio del arzobispado de Sevilla ${ }^{19}$. Aun así, al elaborarse tomando como referencia valores congelados, no podemos hacernos una idea del esfuerzo fiscal que realmente significaba este impuesto año por año. Hasta donde sabemos, los únicos datos publicados para este periodo han sido los de la diócesis de Zamora, donde el subsidio se llevaba el $7 \%$ de las rentas eclesiásticas ${ }^{20}$, por lo que la presión fiscal sería mayor que en Sevilla.

A su vez, para estudiar en manos de quiénes se concentraban el grueso de las rentas del arzobispado de Sevilla y a quiénes correspondía en consecuencia contri-

18. Sobre cofradías y hospitales únicamente se cargaba subsidio en caso de que no hiciesen hospitalidad.

19. Para ello hemos hecho uso de libros de dos tipologías distintas. Por un lado, los denominados "Libros de subsidio", con detalles mucho más pormenorizados, véase ACS, Sección II, 00937B para los años 1567 y 1568, y ACS, Sección II, 00944, para 1578, 1579 y 1580. Por otro lado, tenemos los libros de repartimiento del subsidio, en los cuales figura la cuantía a pagar por cada uno de los partidos fiscales del Arzobispado y las fechas en las que se realizaron los pagos, véase ACS, Sección II, 00942 (1576), ACS, Sección II, 00943 (1577), ACS, Sección II, 00946 (1579).

20. Álvarez Vázquez, 1990. P. 123. 
buir en mayor o menor medida al subsidio de galeras, hemos tomado el año 1579 . En el cuadro 1 podemos observar el reparto de la presión fiscal. Los mayores contribuyentes eran la Mesa Capitular (16,6\%), la Mesa Arzobispal (11,6\%), la vicaría de Sevilla (9,7\%), los monasterios de frailes $(9,24 \%)$. los señores nobiliarios en posesión de tercias $(8,9 \%)$ y las distintas collaciones de la ciudad $(6,1 \%)$. En lo que respecta a vicarías, Sevilla era la que más aportaba económicamente, seguida por Écija (3,5\%), Jerez (3,3\%), Carmona (3\%), Niebla (1,89\%), Arcos $(1,3 \%)$ y Cazalla de la Sierra $(1,2 \%)$.

Una parte considerable de la renta eclesiástica estaba, como acabamos de ver, en posesión de los monasterios de frailes, tanto en los situados en la propia ciudad de Sevilla como en otros lugares de su arzobispado. El más importante de todos ellos era el Monasterio de las Cuevas, que en 1579 poseía frutos por un valor cercano a los 120.000.000 de maravedíes, de los que la Corona extraía 5.854.432 mrs en forma de subsidio. Los dos siguientes, el de San Jerónimo y San Isidoro del $\mathrm{Campo}^{21}$, poseían casi cinco veces menos renta que los cartujos, de manera que en el reparto del subsidio de ese año les correspondió 1.671 .109 y 1.105 .696 mrs, respectivamente ${ }^{22}$.

La participación de la nobleza en rentas eclesiásticas, las denominadas tercias consistentes en los 2/9 de los diezmos, les convirtió en contribuyentes del Subsidio poco tiempo después de su concesión ${ }^{23}$. Durante este periodo el noble que más aportó al subsidio como consecuencia de la percepción de tercias fue el conde de Ureña. Para 1579, se cifraron en 8.529.664 maravedíes los diezmos que percibía de sus feudos de Morón, La Puebla, Arahal y Osuna, de los cuales le correspondía pagar 452.072 de subsidio a la Hacienda Real. Después de él, más alejados pero por encima de la barrera de los 100.000 maravedíes de contribución, nos encontramos, en orden descendente, al duque de Arcos, al conde de Medellín, al marqués de Tarifa y al Marqués de Ayamonte. El duque de Medina Sidonia tributaba 76.108 mrs por la participación en las rentas de sus villas y en el diezmo del aceite de Huelva, Almonte, Tribujena y Monteagudo, y el cabildo y regimiento de la ciudad de Sevilla con $48.980 \mathrm{mrs}$ por los 2/3 del aceite y aceituna que se llevaba de Alcalá de Guadaira. Por último, con cuantías muy escasas, tenemos al Marqués de Villanueva y al conde de Miranda. La nueva tasación efectuada en 1588 no alteraría prácticamente la participación nobiliaria, como podemos comprobar en el libro de subsidio de 1591. El duque de Osuna, antes conde de Ureña, seguía siendo el laico con mayor aportación económica al subsidio, mientras que el marqués de Tarifa ahora pagaba más. Por su parte, desde 1589 al conde de Miranda no se le repartiría subsidio $^{24}$.

21. Vinculado a la orden cisterciense, supone una excepción dentro del marco monástico sevillano, al constituir un señorío de gran autoridad en el plano espiritual y material. Para más información, véase el artículo González Jiménez 2009, pp. 203-206.

22. ACS, Sección II, 00944.

23. Carpintero Aguado 1989, pp. 547-567.

24. ACS, Sección II, 00956. 
Finalmente, hubo otro sector laico que también contribuía al subsidio: los propietarios de juros de pan en las tercias. Su aporte era casi insignificante, al suponer tan sólo $37.668 \mathrm{mrs}$ en 1579. La tónica reinante fue además la exoneración de su pago, de modo que Álvaro de Zúñiga y Juan de Silva se vieron dispensados de tributar por decisión de los jueces del subsidio, mientras que en el caso de Diego Yáñez fue el propio Felipe II quien le concedió franquicia ${ }^{25}$. Si bien por esta fecha el máximo contribuyente era el vizconde de Altamira y su yerno, cuando la nueva tasación elevó el valor de sus rentas desde 510.000 a 1.360 .000 mrs, la Comisaría General de Cruzada resolvió por ejecutoria que a partir de 1593 no se les volviese a carga más subsidio sobre este juro ${ }^{26}$.

2.3. Inmunidad fiscal en el arzobispado de Sevilla: los sectores privilegiados del clero

Un hecho que hemos de tener muy en cuenta a la hora de analizar la problemática de ambas contribuciones es que una parte del clero quedó exonerada de su pago gracias a la obtención de mercedes regias o pontificias que les garantizaba la inmunidad fiscal y les situaba en una posición privilegiada dentro del estamento eclesiástico. La propia naturaleza de estas franquicias, si eran concedidas por el monarca o por el Papa, condicionaba el resultado final de la recaudación, ya que en función de ello su cuantía bien se descontaba o bien se repartía entre los pecheros restantes.

Ciertos sectores que quedaron exentos de su contribución fueron los monasterios de monjas, los cardenales, la Compañía de Jesús, ciertas órdenes militares -como la de San Juan de Jerusalén- o determinados espacios que contaron con la gracia real por algún motivo, véase el monasterio de El Escorial ${ }^{27}$ o el de Santa Clara de Alcocer. Asimismo también tenemos el caso de la Orden de Santo Domingo, a la cual se le dispensó un trato de favor en los repartimientos al establecerla como un sujeto fiscal aparte que contribuía con una cantidad prefijada y, en todo caso, menor a la que realmente le hubiese tocado pagar en relación con su volumen de rentas ${ }^{28}$.

Sabemos que al poco de conocerse la concesión del subsidio de galeras, el Rey Prudente expresó ante la congregación del clero su deseo de que los monasterios de monjas quedasen excluidos de él, proponiendo al estado eclesiástico que se hiciese cargo del dinero que les tocase abonar a las religiosas y, para el siguiente quinquenio, el monarca se los descontaría del total del subsidio. Sin embargo los representantes de los cabildos rechazaron este ofrecimiento, lanzando una contraoferta que fue la que finalmente salió adelante. El acuerdo comprendía un reparto del subsidio a los monasterios de monjas similar al que se hacía con el resto de contribuyentes, con la diferencia de que los colectores no recaudarían ese dinero

25. ACS, Sección II, 00944.

26. ACS, Sección II, 00956.

27. Ulloa, 1986, p. 640.

28. ACS, Sección I, 08904, 08905, 08906, $00953,008907$. 
y el rey lo tomaría a cuenta, no suponiendo así ningún tipo de perjuicio para las iglesias $^{29}$. En 1567 se adoptó esta resolución y fue la que se mantuvo vigente. En el caso del excusado se mantuvieron completamente al margen de su contribución y sus cantidades no figuraban ni tan siquiera como descontadas.

Gracias a los libros de finiquito podemos conocer cuánto dejaron de ingresarse las arcas regias del arzobispado de Sevilla por esta dispensa otorgada a los monasterios de monjas. Según la documentación contable, desde 1563 hasta 1598 -excluyendo la horquilla del segundo quinquenio (1569-1574), cuyo libro se ha extraviado- la monarquía dejó de percibir de la iglesia sevillana cerca de 18.000 .000 de maravedíes por sus monasterios. Éstos habían ido adquiriendo una mayor relevancia conforme avanzaba la centuria, como lo demuestra el hecho de que entre 1563-1568 el descuento oscilaba entre 300.000 y 400.000 maravedíes anuales; años más tarde, entre 1575-1588, la media ya estaba entre el medio millón y los 600.000 maravedíes; y para el último decenio se superó el millón de maravedíes.

En Sevilla encontramos asimismo que una merced eximía de pagar subsidio por las capellanías cantadas en el monasterio de Santa Clara de Alcocer en memoria de los Reyes Católicos. Su status privilegiado le venía desde que en 1377 sus muros habían cobijado una serie de capellanías regias que, por decisión de Enrique II, no serían responsabilidad económica de la comunidad clarisa que las acogía. Los monarcas que le sucedieron se preocuparon por que este emplazamiento continuase siendo un espacio de culto a sus antepasados, garantizando el sufragio de los gastos derivados por las capillas reales. Esto no impidió para que en determinados momentos la comunidad clarisa tuviese que luchar en los tribunales para que se respetasen los arbitrios reales, como el cobro del almojarifazgo de las ollerías de Sevilla o la percepción de las rentas de sal de las salinas de Atienza ${ }^{30}$. Sólo en Sevilla la Hacienda Real dejaba de ingresar de subsidio por estas capellanías 100.000 maravedíes cada quinquenio ${ }^{31}$.

Ya que las cantidades que los monasterios de monjas dejaban de pagar de subsidio eran descontadas, el resto del estado eclesiástico no se veía influido en su contribución. Algo completamente distinto sucedía con las pensiones de los cardenales. La imposición de estas pensiones constituía una prerrogativa regia, que necesitaba de la aprobación de la Santa Sede, mediante la cual compensaban económicamente a cardenales con rentas bajas o a ciertos personajes que hubiesen prestado un servicio determinado a la Monarquía. Lo realmente interesante es que los cardenales no sólo quedaron exentos de contribuir económicamente al subsidio por gozar de estas pensiones, sino que el resto del clero tuvo que asumir aquellas sumas que ellos no pagaban. Y esto fue considerado como un agravio por el estamento eclesiástico, tal y como veremos seguidamente.

La primera información que tenemos acerca de este reparto a posteriori del subsidio correspondiente a las pensiones de los cardenales se remonta a 1565. En

29. Iturrioz Magaña 1988, p. 101.

30. Martín Prieto 2013, pp. 593-594.

31. De forma más exacta: $102.431 \mathrm{mrs}, 4^{\circ}$ quinquenio $104.161 \mathrm{mrs}, 5^{\circ}$ quinquenio $104.074 \mathrm{mrs}$ y $6^{\circ}$ quinquenio $112.887 \mathrm{mrs}$, ACS, Sección I, 08905, 08906, 00953, 008907. 
la congregación del clero celebrada en ese año, el licenciado Arbeloa transmitió confidencialmente a los representantes de los cabildos las intenciones del monarca de cargar los más de 40.000 ducados dejados de pagar por los cardenales sobre las iglesias. Al enterarse de sus propósitos, los procuradores se reunieron en una comisión y en 1567 se pusieron en contacto con el rey a fin de comunicarle el enorme perjuicio que esta decisión tendría para el clero. El monarca sin embargo hizo caso omiso a sus recomendaciones, y decidió seguir adelante con sus acciones. En el momento en que los comisarios generales decidieron asignar la cuantía descontada a las pensiones de los cardenales al resto del estado eclesiástico, las iglesias iniciaron una serie de fallidas acciones judiciales con el objetivo de impedir su reparto, pero ante su fracaso tuvieron que abonar los 94.000 ducados dejados a deber de años anteriores, más comprometerse a saldar desde ahora en adelante el dinero dejado de pagar por los cardenales ${ }^{32}$. Todo ello les resultaría muy gravoso. Como el excusado se basó en el mismo sistema imponible y recaudatorio que el subsidio, las pensiones también se libraron de contribuir a esta nueva carga fiscal.

En base a la documentación manejada hemos podido elaborar unas tablas en las que se recogen las nada exiguas sumas que tuvieron que abonar todas las iglesias por el subsidio y excusado descontados a los cardenales, señalando que en torno al $10 \%$ de dichas cuantías fueron asumidas por la sede sevillana. A la vista de estos datos podemos comprender mejor las reivindicaciones de las congregaciones del clero.

Cuadro 1: Cantidades asumidas por las iglesias en función de las exenciones de las pensiones de cardenales en el subsidio ${ }^{33}$.

\begin{tabular}{|l|r|r|}
\hline \multicolumn{1}{|c|}{ QUINQUENIO } & $\begin{array}{c}\text { ARZOBISPADO DE } \\
\text { SEVILLA (EN MRS) }\end{array}$ & $\begin{array}{c}\text { CONJUNTO DE IGLE- } \\
\text { SIAS (EN MRS) }\end{array}$ \\
\hline $1^{\circ}$ quinquenio (1563-1568) & 1.109 .151 & 12.750 .000 \\
\hline $3^{\circ}$ quinquenio (1575-1580) & 2.698 .831 & 27.176 .347 \\
\hline $4^{\circ}$ quinquenio (1582-1588) & 2.133 .415 & 21.508 .297 \\
\hline $5^{\circ}$ quinquenio (1588-1593) & 4.190 .856 & 42.320 .643 \\
\hline $6^{\circ}$ quinquenio (1593-1598) & 2.072 .400 & 20.996 .942 \\
\hline Total & 12.204 .653 & 124.752 .229 \\
\hline
\end{tabular}

32. Iturrioz Magaña 1988, pp. 71-73.

33. Elaboración propia a partir de ACS, Sección I, 08904, 08905, 08906, 00953, 008907. 
Cuadro 2: Cantidades asumidas por las iglesias en función de las exenciones de las pensiones de cardenales en el excusado ${ }^{34}$.

\begin{tabular}{|l|r|r|}
\hline \multicolumn{1}{|c|}{ QUINQUENIO } & $\begin{array}{c}\text { ARZOBISPADO DE } \\
\text { SEVILLA }\end{array}$ & \multicolumn{1}{c|}{ TOTAL IGLESIAS } \\
\hline $2^{\circ}$ quinquenio (1578-1582) & 996.297 & 9.843 .714 \\
\hline $3^{\circ}$ quinquenio (1583-1587) & 1.138 .626 & 11.250 .082 \\
\hline $4^{\circ}$ quinquenio (1588-1592) & 1.565 .611 & 15.468 .526 \\
\hline $5^{\circ}$ quinquenio (1592-1597) & 1.043 .300 & 10.308 .560 \\
\hline Total & 4.743 .834 & 46.870 .882 \\
\hline
\end{tabular}

Según observamos, estos repartos significaban nuevos desembolsos de cuantías en absoluto desdeñables. Siguiendo lo que nos muestran los cuadros, la carga por subsidio experimentó un considerable aumento entre el primer quinquenio -cuando aún, no lo olvidemos, el monarca no se había pronunciado sobre qué hacer con las pensiones- y el tercero. Después, hay una línea ascendente que afecta a ambas cargas por igual entre finales de los 80 y principios de los 90 , momento en que observamos que las sumas llegan al pico máximo, para luego descender conforme más se cierne el ocaso de la centuria.

\section{RECAUDACIÓN, GESTIÓN Y DESTINO DE LAS CONTRIBUCIONES ECLESIÁSTICAS}

\subsection{Los colectores}

Si bien a principios del siglo XIII las cargas sobre el clero hispano se dirigieron desde una colectoría a cuyo frente solía encontrarse un nuncio papal, la maduración de la autoridad regia trajo consigo demandas de un mayor control sobre estos fondos. En 1482 los Reyes Católicos lograron tras un acuerdo con Domenico Centurione, depositario de la Cámara Apostólica, que el dinero proveniente de las bulas de Cruzada se depositase en las arcas de la Corona. Asimismo también consiguieron una paulatina subordinación de una cohorte de tesoreros, contadores y asesores que acompañaban y ayudaban en sus tareas recaudatorias al Colector General, a los intereses monárquicos. El paso decisivo se dio en 1529, momento en que el cargo de Comisario General se convirtió en permanente y, sobre todo, su elección pasó a ser una prerrogativa más del monarca, aun cuando precisase de una ratificación protocolaria en los breves de concesión promulgados por el

34. Elaboración propia a partir de ACS. Sección I, 08936, 08937, 08938, 08939. Advertir al lector que, en ambas tablas, tanto para el subsidio de galeras como para el excusado, hemos utilizado el maravedí como moneda de cuenta por ser el que aparecía en los libros de finiquito. Sin embargo, las pensiones de estos cardenales estaban situadas en Roma en ducados o escudos de oro, por lo que conviene tener presente el posible cambio de equivalencia monetaria. 
papa $^{35}$. Entre 1575 y 1598 ejercieron, sucesivamente, como colectores generales del subsidio de galeras y del excusado los siguientes personajes: Don fray Bernardo de Fresneda, don Francisco de Soto Salazar, el licenciado don Pedro de Velarde, don Tomás de Salazar, el licenciado don Pedro Puerto y don Francisco de Ávila ${ }^{36}$.

En un escalafón inferior nos encontramos ante una serie de colectores generales del subsidio y del excusado cuya actuación se limitaba a una única sede; y a su vez cada uno de los partidos fiscales tenía a su frente a un subcolector ${ }^{37}$. En el caso de Sevilla, los colectores generales que desempeñaron su cargo durante el reinado de Felipe II ostentaban en su mayoría las prebendas de canónigos y racioneros, y simultaneaban a la par la recaudación del subsidio de galeras y la del excusado ${ }^{38}$. Este perfil que vemos en Sevilla coincide con el proporcionado por Elena $\mathrm{Ca}-$ talán Martínez para el caso calagurritano, a cuyos colectores esta investigadora describe como clérigos de provincias acomodados pero que carecían de contactos financieros que les permitiesen enlazar directamente el dinero con los asentistas o prestamistas internacionales ${ }^{39}$. Entre los colectores generales que ejercieron su cargo en Sevilla durante este periodo sólo encontramos a uno con condición de seglar: Melchor de Albolea Alcázar, quien estuvo al frente tras haber sido designado por el teniente del Asistente de Sevilla en el $4^{\circ}$ quinquenio de subsidio y $3^{\circ}$ de excusado ${ }^{40}$.

Los colectores generales eran comúnmente los responsables de entregar el dinero a la persona que figuraba como beneficiaria en las libranzas firmadas por el Comisario General de Cruzada. De manera excepcional los colectores generales delegaron en otros eclesiásticos esta responsabilidad. Los agentes recibían el dinero dado por los colectores generales del subsidio y excusado en "reales de contado" ante escribano público, y habitualmente el desembolso se hacía en varios días, y no de una sola tajada.

\subsection{Los agentes fiscales}

Para lograr que el dinero de las contribuciones eclesiásticas llegase desde los colectores hasta sus beneficiarios, bien fueran éstos asentistas, propietarios de galeras o receptores de las Gracias de la Real Hacienda, era necesaria la actuación de una serie de intermediarios, a los cuales denominamos agentes fiscales ${ }^{41}$. Estos agentes actuaban como representantes de sociedades, compañías financieras o del propio Estado en un determinado núcleo urbano, permitiendo la comunicación

35. Carlos Morales, Martínez Millán 1991, pp. 903-912.

36. Pérez de Lara 1672, p. 13.

37. La única información que recogen los libros de subsidio de estos subcolectores es su sueldo.

38. La única excepción eclesiástica a esta regla no escrita la encontramos en Alonso Álvarez de Córdoba, arcediano de Niebla, que ejerció como colector del subsidio en el $4^{\circ}$ quinquenio. En ACS, Sección I, 08906.

39. Catalán Martínez 1991, p. 47.

40. ACS, Sección I, 08906 y 08937.

41. Aunque los colectores también actuaban como agentes, su pertenencia a la propia estructura eclesiástica nos ha hecho otorgarle un tratamiento distinto. 
entre recaudadores y destinatarios de las contribuciones económicas. Lo más interesante, no obstante, es ver el perfil de los intermediarios cuando éstos actuaban como delegados de grandes asentistas, puesto que nos revela quiénes eran aquellos pequeños o medianos hombres de negocios castellanos, de escasa visibilidad, y nos permite además observar posibles relaciones entre diversas compañías financieras. Una posible metodología para su estudio podría venir de la mano del Análisis de Redes, dentro de la cual sería interesante analizar las sólidas redes entre mercaderes y factores, si bien para esta investigación no la hemos aplicado. En las siguientes páginas intentaremos ofrecer lo poco que sabemos sobre las relaciones entre asentistas y factores beneficiarios de ambas aportaciones eclesiásticas. Sólo una recopilación y examen sistemáticos de espacios más amplios nos posibilitaría trascender desde lo local hacia una perspectiva más globalizadora.

Para interpretar correctamente la identidad de los agentes fiscales que actuaron como agentes tenemos que fijarnos en primer lugar qué persona, entidad o institución percibía el dinero procedente de estas contribuciones eclesiásticas. En primer lugar veremos quiénes ejercieron como intermediarios cuando el dinero se destinaba a la Real Hacienda y no se derivaba a terceros con los que ésta hubiese asumido previamente un compromiso económico. Entre 1563 y 1568 Domingo de Orbea, en su condición de tesorero y receptor general del subsidio ${ }^{42}$, se valdría de una serie de hombres con un cargo en la Casa de la Contratación para asegurarse de que el dinero le llegaría sin grandes contratiempos. Estos personajes eran: Francisco Duarte, Alejo Salgado Correa, Juan Gutiérrez y Pedro Vaca Cabeza de Vaca $^{43}$, quienes delegaron su responsabilidad ante los colectores en un vecino de Sevilla, Francisco de Torres ${ }^{44}$. Entre 1568 y 1574 asistimos a unos años de vacío documental. En 1575 se creó en la Tesorería General el Arca de las Tres Gracias, un organismo específico encargado de centralizar y distribuir los fondos procedentes de las bulas de Cruzada, subsidio de galeras y excusado ${ }^{45}$, aunque la práctica lo relegaría a la custodia del capital que no nacía ya vencido. Hasta final del reinado de Felipe II, las órdenes de pago dirigidas al arca de las Tres Gracias se giraban sobre Sebastián de Santoyo, Juan Fernández de Espinosa y Ochoa de Urquiza, servidores reales encargados de introducir en ella el dinero. Las contribuciones del arzobispado hispalense dirigidas al receptor general Sebastián de Santoyo pasarían siempre por las manos de Juan Pérez de Santillana, quien además desde 1583 comenzaría a figurar como su lugarteniente ${ }^{46}$. Más interesante aún es conocer las interacciones de Juan Fernández de Espinosa quien entre 1573 y 1587 ocupó el

42. Ocupó este cargo hasta 1564, año en que falleció y fue sustituido por Juan de Orbea. Vid. ACS, Sección I, 08904.

43. Todos ellos tenían una responsabilidad en la Casa de la Contratación: Francisco Duarte era factor, Juan Gutiérrez tesorero, Alejo Salgado contador y Pedro Vaca Cabeza de Vaca, contador interino durante la ausencia de Ortega de Melgosa. En ACS, Sección I, 08904 y AGI, Justicia, 1150, N. 1, R.1.

44. ACS, Sección II, 08904.

45. Carlos Morales 1996, p. 228.

46. Además, Sebastián de Santoyo llegaría a ser ayuda de Cámara del rey, teniendo acceso a su despacho, a algunos gastos secretos y con potestad de conceder audiencias, pero no de remitir memoriales. Al fallecer, le sucedió su hijo Francisco. En Martínez Millán 2014, p. 295. 
cargo de Tesorero General y, simultáneamente, como prestamista privado de la Corona $^{47}$, aunque no se benefició en ningún momento del subsidio y excusado sevillano. Aun así resulta sugestivo que emplee siempre como intermediario a Bartolomé Díez, un jurado de la ciudad de Sevilla que es sin embargo un individuo activo, puesto que lo hallamos ejerciendo como agente de Agavito Grillo y de Baltasar Lomelín. Por último, Ochoa de Urquiza, juez oficial de la Casa de la Contratación desde $1583^{48}$ y encargado de los fondos girados desde Sevilla al arca desde finales de esa década, echará mano de varios agentes, entre ellos Miguel de Aurora, Alonso de Salaya o Martoni de Astorga ${ }^{49}$.

Otro de los usos a los que podía destinarse el dinero recaudado por subsidio o excusado era a proveer armadas y galeras. Cómo repartir y distribuir estos fondos era una obligación de funcionarios regios o de la Casa de la Contratación, tales como Ochoa de Urquiza, Francisco Duarte o Sebastián Santoyo, a quienes les llegaba el dinero mediante agentes de origen peninsular, residentes en Sevilla o en la villa de Madrid, tales como Diego Postigo, Rodrigo Alonso o Pedro Martínez.

Mención aparte merece la actuación de los bancos -afincados tanto en Sevilla como en Madrid-como instrumentos que permitieron enlazar a los colectores con los beneficiarios de ambas rentas extraordinarias. Los primeros se encargaban de depositar en estos bancos los fondos recaudados y, tras la emisión de una orden de pago, los bancos les hacían llegar las sumas hasta sus destinatarios. No fueron sin embargo las instituciones más utilizadas, como lo muestra el hecho que de las cerca de 150 operaciones registradas sólo en 11 estuviesen implicadas bancos públicos. En el siguiente cuadro hemos querido ofrecer información de todas las transacciones en las que hubo una participación bancaria:

Cuadro 3: Participación de los bancos en las transacciones de subsidio y excusado del arzobispado de Sevilla.

\begin{tabular}{|c|c|l|l|l|}
\hline AÑO & $\begin{array}{c}\text { CUANTÍA } \\
(\mathrm{MRS})\end{array}$ & \multicolumn{1}{|c|}{ BANCO } & $\begin{array}{l}\text { CONTRI- } \\
\text { BUCIÓN }\end{array}$ & DESTINATARIO \\
\hline 1575 & 5.294 .485 & $\begin{array}{l}\text { Pedro de Morga y Matía } \\
\text { Fano }\end{array}$ & Subsidio & Lorenzo Espinola \\
\hline 1586 & 1.140 .892 & $\begin{array}{l}\text { Diego de Albuquerque y } \\
\text { Miguel Ángel Lambias }\end{array}$ & Excusado & $\begin{array}{l}\text { Juan Jacome Gri- } \\
\text { maldo }\end{array}$ \\
\hline 1587 & 4.611 .176 & Juan Carmona & Excusado & $\begin{array}{l}\text { Juan Ortega de la } \\
\text { Torre }\end{array}$ \\
\hline 1588 & 4.730 .986 & Juan Carmona & Excusado & $\begin{array}{l}\text { Juan Ortega de la } \\
\text { Torre }\end{array}$ \\
\hline
\end{tabular}

47. Sobre este personaje véase Carlos Morales 1996, pp. 221-238.

48. Donoso Anes, 1996, p. 89.

49. ACS, Sección I, 08905, 08906, 00953, 08907, 08936, 08937, 08938, 08939. 


\begin{tabular}{|c|r|l|l|l|}
\hline 1588 & 4.694 .011 & Juan Carmona & Subsidio & $\begin{array}{l}\text { Juan Ortega de la } \\
\text { Torre }\end{array}$ \\
\hline 1588 & 4.630 .986 & Juan Carmona & Excusado & $\begin{array}{l}\text { Juan Ortega de la } \\
\text { Torre }\end{array}$ \\
\hline 1590 & 4.744 .275 & Juan Carmona & Excusado & Ambrosio Espinola \\
\hline 1591 & 2.000 .000 & Gonzalo de Salazar & Excusado & $\begin{array}{l}\text { Ambrosio Espinola } \\
\text { y Octavio Marín }\end{array}$ \\
\hline 1594 & 5.500 .000 & Gonzalo de Salazar & Subsidio & Martín de Arriaga \\
\hline 1594 & 2.004 .000 & Gonzalo de Salazar & Excusado & Martín de Arriaga \\
\hline
\end{tabular}

De dicha tabla podemos extraer algunas conclusiones. En primer lugar, los bancos fueron empleados indiscriminadamente tanto en operaciones de subsidio como de excusado. En segundo lugar, el nulo aprovechamiento que la Real Hacienda hizo de estos bancos cuando el dinero bien se centralizaba en el arca de las Tres Gracias o bien se surtía para armar a galeras. En tercer lugar, su participación nunca dejó de ser en cierto modo anecdótica. Incluso en los 9 años en que registramos una mayor actividad por su parte, entre 1586 y 1594, únicamente en alrededor del $10 \%$ de las transacciones relacionadas con el subsidio de galeras y del 17\% con el excusado terciaron estos bancos.

La inexistencia de cualquier tipo de intervención bancaria entre 1575 y 1586 se explica por la mala experiencia de 1575 sobrevenida tras la suspensión de pagos decretada por la monarquía. En ese mismo año el colector del subsidio Diego de Sahelices había depositado en el banco de Pedro de Morga y Matía Fano una suma de 5.294.485 mrs, dirigida a Lorenzo Espínola en su condición de asentista de la Corona. Sin embargo, la quiebra de este banco invalidó las libranzas y 4.700.000 maravedíes quedaron en suspenso. La iglesia de Sevilla inició entonces un pleito ante el Comisario General de Cruzada con el fin de que diese por recibida esa cantidad, y en su defensa salió el factor de la Casa de la Contratación Francisco Duarte, alegando que esos 4.700.000 mrs ya habían sido desembolsados al servicio del rey y que iba a enviar relación de los gastos al Consejo de Hacienda para que el Comisario General los diese por buenos. Entretanto, Sevilla no pagó el subsidio que le correspondía en 1576, lo que suscitó la respuesta de la monarquía mediante el envío de un ejecutor que "ejecuta y molesta sobre ellos y aunque quiera empeñarse o tomar a tributo y censo la dicha paga, vendiendo bienes de los capitulares y la fábrica de la dicha iglesia, no puede ahora por la falta que en aquella cibdad ay de dinero"50. El 13 de marzo de 1577 llegó una carta remitida por el Comisario General al cabildo de Sevilla advirtiéndole de la obligación que tenían de pagar los 12.500 ducados a los oficiales que habían llegado desde Madrid ${ }^{51}$. No obstante, hubo que esperar a los tribunales para que este conflicto se resolviese. El juicio enfrentó en el Consejo de Cruzada a ambas partes, en la persona de Luis

50. Memorial sin fecha. Desconocemos si se envió. En ACS, FHG, Caja 111, f. 306.

51. ACS, FHG, Caja 111, f. 359. 
Maldonado como fiscal del rey, y al deán y cabildo en representación de la iglesia de Sevilla. El veredicto le dio la razón al monarca y condenó al cabildo a pagar 11.750 escudos, equivalentes a $4.700 .000 \mathrm{mrs}$, en $1578^{52}$. La siguiente ocasión en la que se confió nuevamente en una entidad bancaria fue en 1586, con Diego de Albuquerque y Miguel Ángel Lambias, disuelta no obstante un año más tarde. Los siguientes que se convirtieron en fiduciarios de fondos eclesiásticos fueron Juan Carmona y Gonzalo de Salazar, asociados y uno de los principales bancos públicos de la villa de Madrid $^{53}$, que monopolizaron todas las transacciones entre 1587 y 1595 pero que tuvieron una disruptiva y corta trayectoria en la ciudad del río Betis $^{54}$.

Tanto subsidio como excusado podían destinarse a los pagadores de galeras, una de cuyas funciones era la guarda de las cantidades libradas por la Real Hacienda y el aprovisionamiento de las galeras ${ }^{55}$. Uno de ellos era Martín de Arriaga, al servicio del rey desde 1578, más tarde nombrado pagador general de las galeras de España y cuya muerte sobrevino al poco de ser designado como embajador en Marruecos $^{56}$. Puede que Martín de Arriaga no tuviese demasiados contactos con agentes sevillanos, ya que de tres órdenes de pago giradas sobre él en dos utilizó a bancos públicos como enlaces, y en la otra ocasión facultó a un tal Martín de Vergara como cesionario, quien dio poderes a una serie de personas que hicieron lo mismo con otras tantas, de manera que los colectores tuvieron que entregar el dinero a 18 colectores distintos. El otro pagador que aparece es Juan Pascual, quien una de las veces recoge él personalmente el dinero de manos de los colectores, y el resto usa como agente intermediario a Pedro Martínez.

Por último, podía ser que las sumas de estas contribuciones eclesiásticas se destinasen a pagar asientos contraídos previamente con prestamistas naturales del reino o extranjeros. La propia configuración de las compañías que integraban estos hombres de negocios explica en buena medida el perfil de los agentes fiscales que hallamos en sus operaciones. Era muy habitual que los socios de estas sociedades perteneciesen a una misma familia, y que actuasen a su vez como albaceas, cesionarios o agentes en transacciones de su propia compañía. Pongamos un par de ejemplos. En 1575 la Real Hacienda había mandado que se destinase una parte del subsidio a Lorenzo Espinola en atención a un asiento que había sido concertado con él unos años antes, y que había servido para armar a la expedición de la Liga Santa. Los colectores depositaron el dinero en la entidad bancaria de Pedro de Morga y Matía de Fano, pero fue un familiar suyo, Bautista Espinola, el encargado de tomar ese dinero ${ }^{57}$. Algo parecido sucede con el subsidio de 1587, cuando la monarquía dio orden de pago a Baltasar Lomelín para saldar un asiento con él, y sea su pariente Joan Bautista Lomelín quien le ceda el poder a un genovés resi-

52. ACS, Sección I, 08905.

53. Vid. García Guerra 2006, p. 303, y Martín-Aceña, Nogues-Marco 2013, p. 149.

54. Domínguez Ortiz 1991, p. 65.

55. Marchena Giménez 2010, p. 132.

56. Dávila 1971, pp. 776-777.

57. ACS, Sección I, 08905. 
dente en la ciudad de Sevilla, de nombre Carlos Vimaldo, para que le haga llegado el dinero recaudado por los colectores eclesiásticos ${ }^{58}$.

Junto a estos hermanamientos, que constituyeron un modus operandi hasta cierto punto frecuente, hubo también otro tipo de interacciones entre socios de distintas sociedades financieras. De este modo observamos a miembros de familias tan importantes como los Marín, los Espinola o los Centurione actuar como agentes de los Grimaldo, De Negro o Grillo, respectivamente. Estas compañías genovesas empleaban, aparte de a compatriotas suyos, a intermediarios castellanos, como serán Francisco Alonso de Maluenda, Antonio Muñoz o Bernardo de Saavedra, personajes que permanecerán hasta cierto punto en un anonimato documental $^{59}$. Asimismo sus agentes podían trabajar a un mismo tiempo para varias compañías genovesas simultáneamente, como lo demuestra el hecho de que Carlos Buron ejerciese al mismo tiempo como enlace en las transacciones de Héctor Picamilio y de Sinibaldo Fiesco y Juan Bautista Justiniano.

En el caso de las compañías integradas por asentistas naturales, como podían ser los Ortega de la Torre, los Maluenda o los Vitoria, emplearon siempre en todas sus transacciones a agentes fiscales castellanos lo que, como vemos, supone una diferenciación con respecto a los genoveses. Francisco y Pedro de Maluenda utilizaron en todas ellas -salvo una, en 1595, en la que sólo intervino el vecino de Sevilla Juan de Castro- a Francisco de Bobadilla, quien encomendó a los siguientes cesionarios percibir el dinero recaudado: Sebastián de Galdós, Sebastián Delgado y Juan Pascual. El entramado se complica aún más si advertimos que tanto Sebastián Delgado como Juan Pascual delegaron a su vez en Sebastián Yáñez y Francisco de Ibarra para dichas gestiones. Los hermanos Vitoria utilizaron por su parte a distintos intermediarios, entre los que podemos citar a Pedro de Tolosa, Jerónimo de Jáuregui o Gabriel de Velasco. Ni los agentes empleados por los Maluenda ni por los Vitoria tenían exclusividad con sus compañías. Por ejemplo en un mismo año, 1593, podemos encontrarnos con Pedro de Tolosa actuando como cesionario de los hermanos Vitoria y a la misma vez percibiendo de los colectores el dinero que pertenecía a Octavio Marín y Ambrosio Espinola, tras haber obtenido un poder de Lorenzo Martínez que le autorizaba para ello.

La demora en el pago a algunos asentistas provocó que, para cuando el Consejo de Hacienda resolvió y destinó las rentas con que cubrir sus deudas, éstos ya hubiesen muerto, figurando entonces sus viudas, socios o acreedores como destinatarios. Mostramos dos ejemplos que nos hemos encontrando. Tras el fallecimiento de Agavito Grillo, la orden de pago para el subsidio de 1590 pasó a beneficiar a sus herederos o testamentarios, que a la sazón eran su viuda Lucía y Lacano de Grimaldo. Ambos facultaron a Julio de Espinosa, quien delegó a su vez en Agustín de Vicaldo, para que tomase los dos millones y medio de maravedíes

58. ACS, Sección I, 08906

59. En el caso de Francisco Alonso de Maluenda era miembro de la conocida familia de mercaderes y financieros burgaleses. Sin embargo, parece ser que no tuvo demasiada suerte en los negocios y que una de sus actividades se centró en el cobro de los juros situados en los almojarifazgos. En Lorenzo Sanz 1992, p. 430. 
que le alcanzaban los colectores de Sevilla. Más compleja aún fue la situación dejada por Baltasar Lomelín tras su defunción. Baltasar Lomelin era acreedor de Julio Espinola, a quien la monarquía pagó más de la mitad del asiento que le debía a través del subsidio de 1591. Tras la muerte de Baltasar Lomelin, la justicia de Madrid, en nombre de su viuda Palma de Grimaldo, asignó a Héctor Picamilio como administrador y albacea de sus bienes, y gracias a esta gestión pudieron cobrar la parte que les debía Julio Espinola.

\subsection{El destino de las contribuciones eclesiásticas de la iglesia de Sevilla}

La propia configuración de la Monarquía Hispánica y de sus actuaciones en el plano internacional condicionó en gran medida la construcción de un sistema hacendístico erigido más en base al gasto que al ingreso ${ }^{60}$. Esto no suponía una excepción, sino que más bien se integraba en una dinámica coherente dentro de la lógica política los Estados del Antiguo Régimen, que buscaban desplegar su hegemonía mediante su ampliación y consolidación territorial, con los consabidos costes económicos que ello suponía. Inmersa en esta incesante búsqueda de nuevos ingresos, la monarquía halló en los recursos eclesiásticos una fuente bastante codiciada por los hombres de negocios, entre otras cosas por su alto índice de fiabilidad. De ahí que, cuando observemos las negociaciones entre Carlos V y los banqueros alemanes de Augsburgo, veamos que las rentas eclesiásticas se encuentran en segundo orden de preferencia -sólo después del servicio de Cortes-, junto a otros ingresos como las remesas venidas desde América ${ }^{61}$. Aunque en teoría, siguiendo los breves pontificios, los fondos del subsidio de galeras debían destinarse a pertrechar las embarcaciones que luchaban contra los otomanos en las aguas mediterráneas, y los del excusado a luchar contra los herejes del norte de Europa, sin embargo ambos tributos fueron utilizados en muchas ocasiones para cubrir otros compromisos financieros que nada tenían que ver con esto. En las siguientes páginas analizaremos en qué partidas empleó la Monarquía los recursos eclesiásticos del arzobispado de Sevilla durante este periodo.

Las órdenes de pago para el primer quinquenio del subsidio de galeras (15631568 ) están incompletas, debido al mal estado de conservación en que se encuentra el libro que las recoge. En 1563 el arzobispado de Sevilla libró cerca de 6 millones y medio de maravedíes a los Fugger, en cumplimiento al compromiso que la monarquía había adquirido con Christopher Hermann, uno de sus representantes legales, a fin de reintegrarle 200.000 ducados en la paga del subsidio entre el 30 de junio y el 31 de octubre de ese mismo año. Aunque en base a la documentación Sevilla cumplió con su parte, la morosidad de ciertas iglesias provocó una dilación del pago a estos banqueros alemanes hasta 1564. Otra de las libranzas registradas para este quinquenio se dirigieron a favor del Conde de Chinchón, imaginamos que en su condición de Tesorero General de la Corona de Aragón. Otro de los

60. Marcos Martín 2013, pp. 124-125.

61. Carretero Zamora, Galán Sánchez 2013, p. 487. 
pagos se destinó a Lucian Centurión, propietario de galeras, y en contrariedad con los datos aportados por I. Cloulas, ya aparece como beneficiario para el año $1566^{62}$. Los Centurión pertenecía a una de esas familias genovesas, junto a los Doria, los Lomelín, Spínola, Grimaldi o Grillo, que había invertido desde principios de siglo en el asiento de galeras. Finalmente constan pagos a personajes como los genoveses Agustín Gentil o Vizconte Catano.

Por desgracia no tenemos ningún registro de los pagos efectuados para el subsidio de galeras entre 1568 y 1574 por el arzobispado de Sevilla. Igualmente tampoco ha llegado hasta nosotros el libro del primer quinquenio del excusado (1573-1577). Ambas pérdidas se sitúan además en una marco que habría resultado de gran relevancia conocer, por su cercanía cronológica a la conocida suspensión de pagos del año 1575, que la historiografía ha abordado de manera tan dispar. La línea de interpretación tradicional estaría marcada por los argumentos de A. Lovett, al considerar que la sobreabundancia de los compromisos adquiridos por la monarquía filipina colapsó el sistema de pagos ${ }^{63}$. En términos similares, aunque con un razonamiento bastante menos consistente, se expresó también J. Conklin, al defender que el techo de deuda se hallaba entre los 7 y los 9 millones de ducados, y en esas fechas se sobrepasó. Por el contrario, otros autores han relativizado los índices de esa deuda pública, comparándola con la existente en otros países europeos del entorno, también sumidos en conflictos bélicos ${ }^{64}$. Finalmente, hay quienes han visto en esta suspensión de pagos una estrategia monárquica para liberarse de la dependencia del crédito genovés ${ }^{65} \mathrm{o}$ forzar a las cortes a aumentar el encabezamiento de las alcabalas ${ }^{66}$.

De ahí que únicamente nos sea posible aportar por completo el destino de las contribuciones sevillanas a partir de 1575. A fin de hacer más inteligible dicha información hemos elaborado unos gráficos en los que podemos observar por quinquenios a qué gastos se destinaron las libranzas cargadas sobre los subsidios de galeras y excusados del arzobispado de Sevilla. El complejo análisis que requiere dicha información nos ha llevado a adoptar una división metodológica que fijase las cuatro posibles categorías en que fue empleado el dinero de ambas contribuciones: arca de las Tres Gracias ${ }^{67}$, anticipos ${ }^{68}$, asientos y gastos de galeras ${ }^{69}$.

62. Cloulas 1967 , pp. 360-308.

63. Lovett 1980, pp. 899-911.

64. Drelichman, Voth 2010, pp. 813-842.

65. Ruiz Martín 1990.

66. Álvarez Nogal, Chamley 2013, pp. 187-211.

67. Significa que de dinero se dirige a la Hacienda Real, donde más tarde se distribuirán teóricamente en los efectos para los que fueron recaudadas estas rentas eclesiásticas.

68. Prestamistas castellanos que, como Juan Ortega de la Torre, adelantan una parte de su dinero a la Hacienda Real, siéndoles devueltas dichas cantidades cuando se recauda el subsidio o el excusado. Tal y como figura en los libros de finiquitos, parece que dichos anticipos no revertía ningún tipo de comisión.

69. Bajo esta denominación incluimos gastos derivados de sueldos, provisiones y abastecimiento de las galeras. 
Evolución por quinquenios asignaciones subsidio en maravedíes

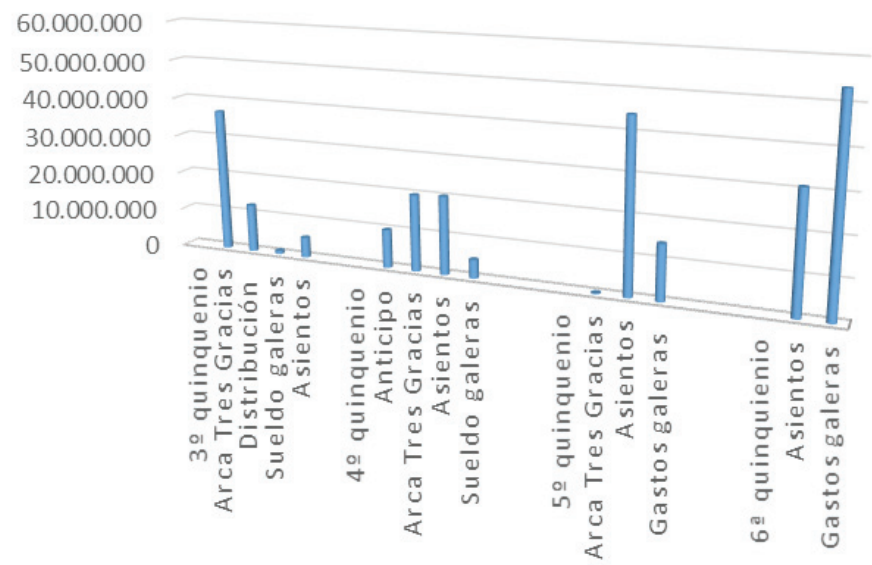

Evolución por quinquenio de las asignaciones del excusado en maravedíes

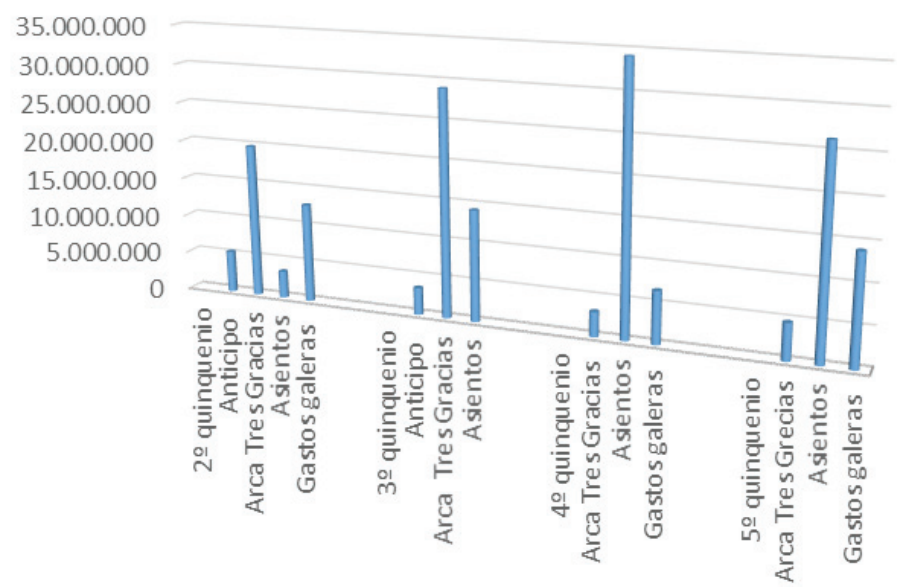

En base a los registros del subsidio de galeras podemos señalar que la suspensión de pagos acabó momentáneamente -salvo una excepción que ahora explicaremos- con una práctica de la Real Hacienda que se había convertido en cotidiana desde tiempo atrás: el uso de rentas eclesiásticas como garantía de pago de los asentistas internacionales. Esta paralización sólo fue temporal y tuvo efecto 
durante pocos años. La única salvedad en el caso de la sede sevillana durante este periodo fue la libranza de 5.294.485 maravedíes emitida a nombre de Lorenzo Espinola en 1575, en razón a una cédula que ordenaba la liquidación de 1254.5000 de maravedíes, más los intereses de demora, por dos asientos que habían sido suscritos con este prestamista genovés en mayo de 1571 y en diciembre de 1572 . Y es que Lorenzo Espinola recibiría un trato de favor una vez decretada la suspensión de pagos, siendo junto a los Fugger y el Tesorero Real Fernández de Espinosa ${ }^{70}$. Posiblemente esta privanza se deba a su compromiso de proveer de liquidez a las tropas de Flandes y a las armadas que debían luchar contra los otomanos ${ }^{71}$. El resto de las sumas recaudadas en concepto de subsidio y de excusado entre $1575 \mathrm{y}$ 1580 fueron introducidas en el arca de las Tres Gracias o entregadas a factores de la Casa de la Contratación, cuyo cometido era emplearlas en equipar a las galeras.

A principios de 1580 esta dinámica cambió, y tanto en el caso del subsidio de galeras como del excusado comenzamos a ver que comienzan a utilizarse para pagar asientos. Será sin embargo en la segunda mitad de cuando se produzca un incremento del dinero librado en la devolución de préstamos, dato que tiene su explicación si lo relacionamos en un contexto bélico con presencia española en la guerra con Francia y con el que han comenzado los preparativos de la Armada Invencible $^{72}$. Esta tendencia no obstante se mantendrá durante toda la primera mitad de la década de los 90 . Un dato muy significativo es que durante estos años el caudal destinado al arca de las Tres Gracias fue escasísimo, prácticamente testimonial en un escenario económico predominado por el compromiso impuesto por una acrecentada deuda flotante. Este desvío de los recursos fiscales hacia campañas militares exteriores no atañó únicamente a las rentas eclesiásticas, sino que era extensible a otras, tanto ordinarias como extraordinarias.

La cuarta y última suspensión de pagos del reinado de Felipe II se decretaría el 29 de noviembre de 1596. Al igual que sucedía con la de 1575, esta decisión también repercutió en el destino de las libranzas emitidas sobre contribuciones eclesiásticas. En el caso del subsidio de galeras, hasta la muerte del monarca dos años después no volvió a girarse una orden de pago que tuviese como destinatario a un asentista. Más curioso resulta lo que atañe al excusado, ya que a pesar de que la Real Hacienda no destinó ningún pago a asentistas con los que hubiese suscrito asientos, sí lo hizo con los acreedores de estos financieros. Como consecuencia de esta política se beneficiarían Bautista de Gallo, Antonio de San Román y Juan de Oviedo, en su calidad de consignatarios de Agustín de Espinola y Nicolao de Negro; y lo mismo hicieron Bernardo y Leonis Martín por serlos de los burgaleses Francisco y Pedro de Maluenda.

Una de las informaciones más valiosa que nos aporta esta documentación es que a pesar de que el Consejo de Hacienda no hizo, a efectos prácticos, distinciones entre los teóricamente distintos fines que debían de alcanzar el subsidio y el excusado, ideológicamente el primero había sido instituido para equipar a las

70. Carlos Morales 1996, pp. 221-237.

71. Lovet 1982, p. 12.

72. Carlos Morales 1996, pp. 221-237. 
galeras del Mediterráneo y el segundo para combatir a los herejes del norte de Europa. Sin embargo, el siguiente gráfico que hemos elaborado desmonta esta construcción discursiva, al mostrar que el destino de las contribuciones de una y otra fue prácticamente el mismo ya que ambas se utilizaron para liquidar las deudas impuestas por las exigencias del momento.

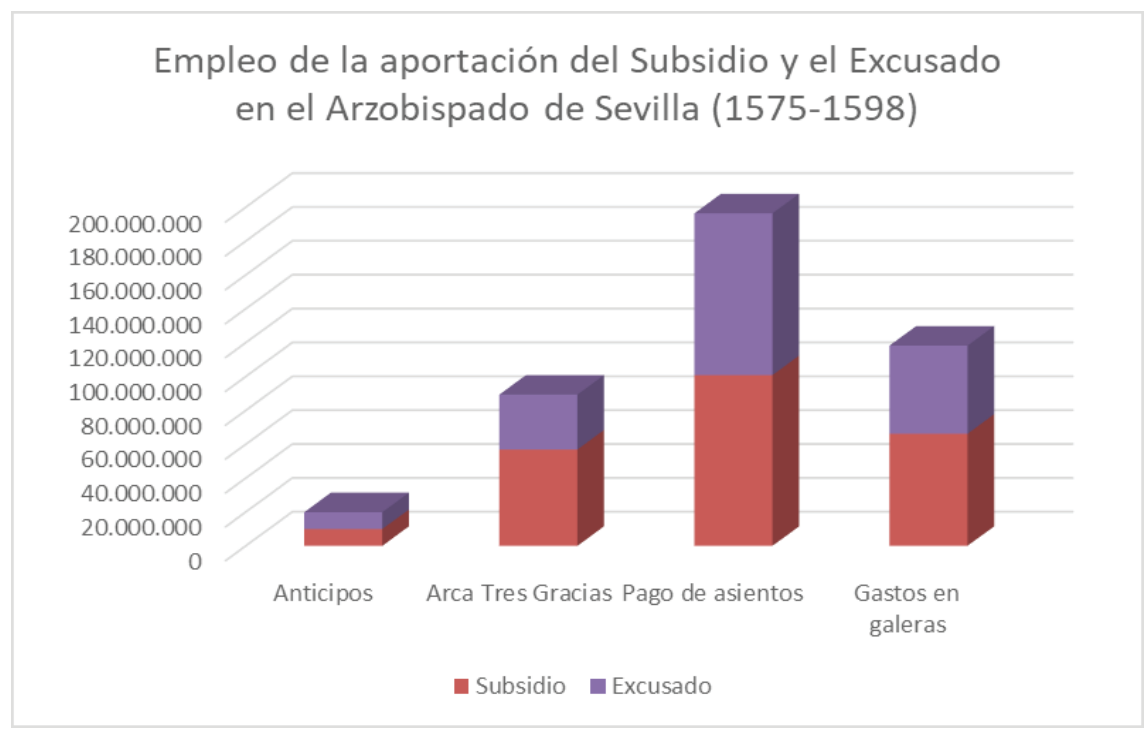

La procedencia de los asentistas es otro de los elementos susceptible de análisis, al permitirnos interpretar mejor ciertas dinámicas, como seguidamente veremos. A nadie se le escapa que nos encontramos, parafraseando a Felipe Ruiz Martín, en el Siglo de los Genoveses ${ }^{73}$, por lo cual resulta comprensible que la mayor parte de las órdenes de pago les tuviese a ellos como protagonistas. La representación genovesa que encontramos pasa por los siguientes financieros: Lorenzo Espinola, Agustín Espinola, Juan María Corvari, Baltasar Lomelín, Ambrosio Espinola, Felipe Lomelín, Julio Espinola, Nicolao Doria, Julio Gentil, Jacome Espinola, Octavio Marín, Bautista de Franquis, Aníbal Cambi, Héctor Picamilio, Sinibaldo Fiesco, Juan Bautista Justiniano y Nicolao de Negro. Ninguno de estos nombres pueden sernos indiferentes, ya que todos ellos pertenecían a alguno de los grandes albergos genoveses que habían ostentado tradicionalmente el poder político y económico de la República. Desde mediados del siglo XV ya encontramos a miembros pertenecientes a los Lomelín, Grimaldo o Gentil ejerciendo como cónsules de su comunidad en Sevilla ${ }^{74}$. Sin embargo también es cierto que su predominio no fue homogéneo durante todo el reinado de Felipe II. Una pequeña evidencia de ello lo tenemos en el siguiente gráfico:

73. Ruiz Martín 1965, p. XXX.

74. González Arce 2010, p. 181. 


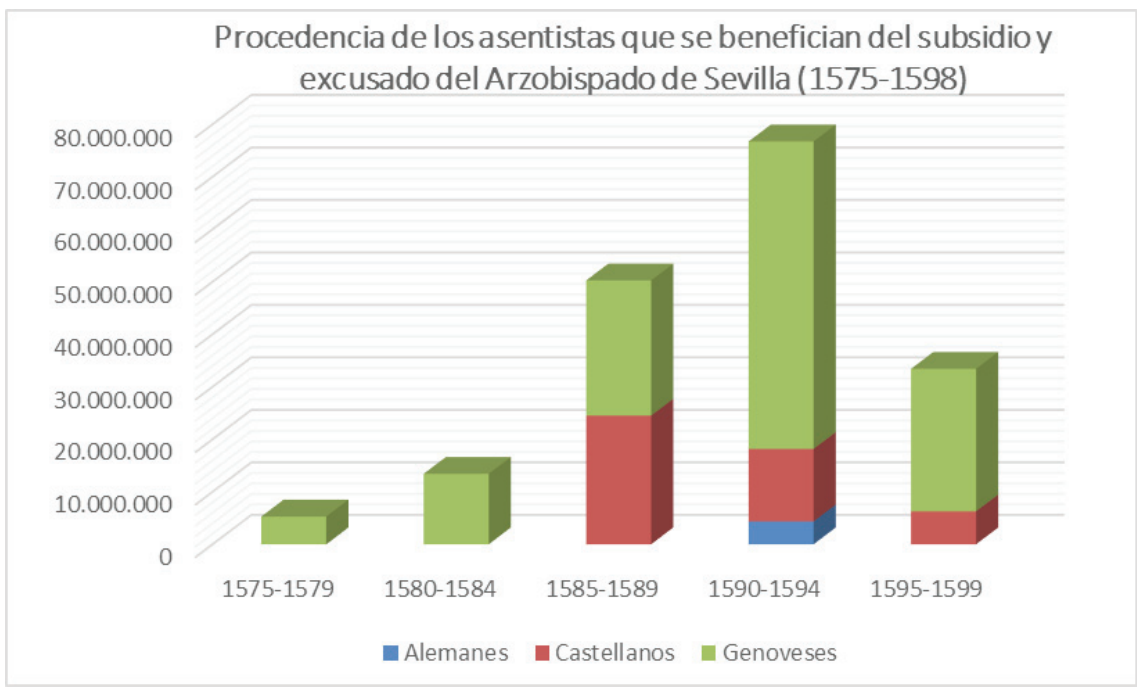

Si bien la historiografía nos dice que tras la bancarrota de 1575 Felipe II intentó zafarse sin demasiado éxito de la dependencia financiera genovesa suscribiendo asientos con banqueros de otras nacionalidades, como castellanos, portugueses, franceses o florentinos, en base a nuestra documentación este cambio de tendencia no lo percibimos hasta la segunda mitad de la década de los 80 . Es en ese periodo cuando las libranzas giradas al burgalés Juan Ortega de la Torre igualaron a las del conjunto de genoveses ${ }^{75}$. Sin embargo, una vez que se reanudaron con mayor virulencia los conflictos bélicos, la monarquía volvió a confiar en asentistas genoveses, que se beneficiaron una vez más de las contribuciones eclesiásticas. No obstante el capital castellano siguió teniendo una presencia, aunque más discreta, gracias a la actividad crediticia de los hermanos Vitoria o de los Maluenda. Esto no impidió que los genoveses acaparasen, como antaño, el odio de algunos castellanos cercanos a los círculos de poder ${ }^{76}$.

Finalmente, señalar que la presencia alemana, prácticamente inexistente por otro lado, se circunscribió a la familia Fugger. La únicas libranzas sobre contribuciones eclesiásticas giradas a los Fugger dataron de 1563 y de 1590, esta última coincidiendo con el deshielo en las relaciones entre Felipe II y esta familia de prestamistas, que tuvo lugar justo después de la derrota de la Armada Invencible ${ }^{77}$.

75. Juan Ortega de la Torre pertenecía a la familia de los Torres. Para 1581 su importante banco contaba con sucursales en Valladolid, Medina del Campo, Burgos, Amberes, Madrid y Sevilla. Vid. En Lorenzo Sanz 1992, p. 432.

76. Dicha inquina venía desde lejos. Antes de 1575 encontramos numerosos testimonios al respecto. Uno de los más destacados es el de fray Tomás de Mercado, para quien los genoveses habían penetrado en el mundo de los negocios "como aves de rapiña, a comerles las carnes con cambios y recambios, así a los príncipes como a los particulares”. En Carlos Morales 1999, p. 72.

77. Kellenbez 2000, p. XIII. 
Al poco de ocupar el trono, Felipe III reconoció que el dinero de las contribuciones eclesiásticas se había estado gastado indebidamente y ordenaba una serie de medidas para que se empleasen según lo estipulado en el breve papal. Su compromiso pasó por armar a un mínimo de 40 galeras y flotar cuantas se pudiesen con los recursos sobrantes, así como restringir el empleo de los fondos de Cruzada, Subsidio y Excusado al Consejo de Cruzada y al Comisario General, para que el Consejo de Haciendo no pudiese disponer libre y arbitrariamente de ellos como hasta entonces se había hecho ${ }^{78}$. Sin embargo las promesas de Felipe III se quedaron en eso, y en la práctica el Consejo de Hacienda continuó decidiendo a qué partidas debía destinarse el dinero de las Tres Gracias ante la mirada exculpatoria del monarca ${ }^{79}$.

\section{CONCLUSIONES}

La maduración de los sistemas fiscales en buena parte del occidente europeo es, posiblemente, uno de los múltiples actores que nos permite explicar la génesis e institucionalización de esa entelequia intelectual a la que llamamos Estado Moderno. Uno de los elementos que nos posibilitaría identificar a este nuevo aparato burocratizado sería el perfeccionamiento y la consiguiente extensión de las estructuras tributarias hacia todos los súbditos, incluyendo al estamento eclesiástico. Si bien no podemos caer a engaño pensando que la apropiación de los recursos eclesiásticos constituye un fenómeno moderno, al hundir sus raíces en la Edad Media, tendremos que esperar hasta el siglo XVI para que esta práctica adquiera un carácter completamente ordinario y regular. Estas exacciones de recursos se produjeron con el beneplácito más o menos explícito de los distintos sucesores en el Trono de San Pedro, que se vieron obligados a abandonar sus pretensiones universalistas en pos de las nuevas realidades dinásticas que se impusieron, y cuyas manifestaciones más tangibles se materializaron en el consabido Cuius regio, eius religio. Aun así, pese que a los pontífices consintiesen la arrogación por parte de los príncipes de una parte de los recursos del clero de su reino, sus representantes capitulares se alzaron en muchas ocasiones, tratando de forzar mediante la vía de la negociación mejores condiciones de pago. Esta pulsión y correlación de fuerzas entre Iglesia y Monarquía pueden observarse perfectamente mediante el estudio de las actas de las congregaciones del clero, las cuales no han sido sometidas aún, según nuestro punto de vista, al análisis sistemático que merecen.

Hemos visto cómo el arzobispado de Sevilla contribuía con cerca del 10\% de la cuantía total a pagar en concepto de subsidio y excusado, lo cual supone un porcentaje nada desdeñable y brinda a nuestra sede de una cierta representatividad. Es precisamente en la tributación de la segunda renta donde encontramos una mayor conflictividad en tanto en cuanto la tasación se hacía teniendo como referencia

78. Cédula del 4 de abril de 1603, en ACS, FHG, Caja 111, 1, ff.49-53.

79. Carpintero Aguado 1993, p. 162. 
todas las rentas eclesiásticas, y no únicamente las decimales, lo cual fue denunciado reiteradamente por sus diputados en las congregaciones del clero, aunque sin éxito. Descendiendo de escala, el prorrateo interno efectuado dentro del arzobispado llevó aparejado una idea de igualdad distributiva, pero no de compensación de los posibles desequilibrios regionales. Nos explicamos. Pese a que todos los cuerpos eclesiásticos vieron deducidos en torno al $8 \%$ de sus rentas en concepto de subsidio y excusado, este gravamen no podía afectar por igual a aquellas instituciones que manejaban elevados ingresos frente a unas parroquias rurales cuyos beneficiados sobrevivían a base de derechos de pie de altar y otras donaciones de su feligresía. Por no hablar de las franquicias o descuentos aplicados a personas o instituciones que por diversos motivos interesaban a la Corona, como servidores reales, nobles, la Orden de Santo Domingo, la Compañía de Jesús, los monasterios de monjas o las pensiones de los cardenales. Fue precisamente esta última, concedida por la Santa Sede, a la que se opusieron con mayor virulencia los cabildos al no suponer una exención, sino un nuevo reparto en el que todos tenían que contribuir y que era bastante gravoso, tal y como hemos expuesto en los cuadros 2 y 3. Sin embargo, no todo el sistema hacendístico perjudicaba económicamente a las iglesias. En el caso de Sevilla, la congelación de las rentas eclesiásticas desde 1588 hasta finales del siglo XVII suponía, acorde a la coyuntura inflacionaria, que si devengamos sus rentas el clero cada vez contribuyó con menos dinero a la Monarquía, en términos reales. Podemos hablar en cierto modo de una renuncia del poder regio a establecer un control directo de la fiscalidad eclesiástica -que hubiese supuesto, entre otras cosas, conocer los ingresos de las distintas diócesis-, a cambio de percibir unos ingresos constantes y periódicos de la Iglesia.

Uno de los logros obtenidos por la Corona se acometió en el terreno de la recaudación de estas rentas eclesiásticas, que dejaron de estar subordinados a intereses pontificios para depender de los monarcas. En cuanto a los colectores generales de la iglesia de Sevilla, en su inmensa mayoría eran canónigos y racioneros, lo cual implicaba un perfil intermedio dentro de la jerarquía eclesiástica. Estos colectores generales eran los encargados de entregar el dinero a los destinatarios signados por el Consejo de Hacienda. Su perfil variaba en función de qué persona particular, compañía o institución percibía en última instancia la contribución eclesiástica.

Por último, más interesante resulta aún si cabe el uso que dio la Monarquía a estas aportaciones económicas. Su empleabilidad dependió en gran medida de los compromisos exteriores y en consecuencia de la necesidad de recursos que tuviese en aquellos momentos la Real Hacienda. Desde la suspensión de pagos de 1575 hasta mediados de los años 80 , observamos más liquidez y, hasta cierto punto, una mayor previsibilidad en el empleo de los recursos financieros, destinados en buena medida al arca de las Tres Gracias y a pagar el sueldo de las galeras. Sin embargo, desde este momento hasta la suspensión de pagos de 1596 la tónica general fue que las contribuciones eclesiásticas se destinasen a cumplir los compromisos contraídos previamente con asentistas que habían proveído fondos, mayoritariamente en Flandes y en la Península Itálica. Tal fue la supuesta mala praxis que se le dio tanto a subsidio como a excusado, que nada más subir al trono Felipe III hizo una 
declaración de intenciones, señalando que a partir de ese momento sería la Comisaría General la encargada de decidir quiénes serían los beneficiarios de dichos fondos. Sin embargo, sabemos que esto nunca se llevó a cabo, y que la Monarquía continuó echando mano de las rentas eclesiásticas en cuanto las necesidades fiscales la acuciaban, y necesitaban cubrir con premura la cada vez más acrecentada deuda flotante del Estado.

\section{APÉNDICE}

Cuadro 4: Repartimiento del subsidio de galeras entre los contribuyentes del Arzobispado de Sevilla para el año $1579^{80}$

\begin{tabular}{|l|r|r|}
\hline \multicolumn{1}{|c|}{ CONTRIBUYENTE } & $\begin{array}{r}\text { VALOR RENTAS } \\
\text { ECLESIÁSTICAS }\end{array}$ & $\begin{array}{c}\text { CARGO } \\
\text { SUBSIDIO }\end{array}$ \\
\hline Mesa Capitular & 39.398 .756 & 2.088 .132 \\
\hline Mesa Arzobispal & 27.437 .521 & 1.454 .188 \\
\hline Vicaría de Sevilla & 23.553 .125 & 1.223 .559 \\
\hline Tercias propiedad de señores & 29.890 .793 & 1.118 .456 \\
\hline Collaciones de Sevilla & 14.750 .684 & 775.852 \\
\hline Monasterios de frailes de Sevilla & 12.462 .825 & 660.577 \\
\hline Monasterios arzobispado de Sevilla* & 9.457 .755 & 497.240 \\
\hline Fábrica de la Iglesia & 8.919 .867 & 472.749 \\
\hline Vicaría de Écija & 8.751 .768 & 438.675 \\
\hline Vicaría de Jerez & 7.999 .434 & 420.590 \\
\hline Vicaría de Carmona & 7.108 .069 & 376.062 \\
\hline Monasterios de monjas de Sevilla2** & 6.407 .494 & 339.276 \\
\hline Vicaría de Niebla & 4.541 .880 & 237.304 \\
\hline Vicaría de Arcos & 3.733 .843 & 164.674 \\
\hline Vicaría de Cazalla de la Sierra & 2.975 .732 & 156.475 \\
\hline Vicaría de Sanlúcar la Mayor & 2.856 .840 & 151.592 \\
\hline Capellanías de la Fábrica & 2.674 .716 & 140.760 \\
\hline Vicaría de Tejada & 2.631 .835 & 129.679 \\
\hline Vicaría de Cumbres Mayores & 2.528 .760 & 126.888 \\
\hline Vicaría de Constantina & 2.225 .700 & 122.950 \\
\hline Vicaría de Santa Olalla & 1.972 .023 & 104.511 \\
\hline Vicaría de Lebrija & 1.621 .312 & 85.920 \\
\hline
\end{tabular}

80. Elaboración propia a partir de ACS, Sección II, 00944. 


\begin{tabular}{|c|c|c|}
\hline CONTRIBUYENTE & $\begin{array}{l}\text { VALOR RENTAS } \\
\text { ECLESIÁSTICAS }\end{array}$ & $\begin{array}{c}\text { CARGO } \\
\text { SUBSIDIO }\end{array}$ \\
\hline Vicaría del Puerto de Santa María & 1.454 .409 & 83.658 \\
\hline Vicaría de Huelva & 1.741 .296 & 82.188 \\
\hline Vicaría de Sanlúcar de Barrameda & 1.467 .178 & 77.758 \\
\hline Prior de Aracena & 1.455 .494 & 77.143 \\
\hline Beneficiados de la Veintena & 1.394 .419 & 73.904 \\
\hline Vicaría de Moguer & 1.300 .438 & 68.894 \\
\hline Vicaría de Gibraleón & 1.189 .907 & 63.061 \\
\hline Capellanías del Cabildo & 1.207 .916 & 63.020 \\
\hline Vicaría de Alanís & 998.349 & 53.853 \\
\hline Vicaría de Aracena & 743.730 & 40.937 \\
\hline Capilla de la cárcel & 772.131 & 40.923 \\
\hline Vicaría de Lepe & 746.508 & 39.549 \\
\hline Juros de pan propiedad de señores & 1.350 .936 & 37.668 \\
\hline Prior del Puerto de Santa María & 696.149 & 36.896 \\
\hline Hospitales del Arzobispado de Sevilla & 657.091 & 33.358 \\
\hline Vicaría de Cantillana & 619.384 & 32.824 \\
\hline Vicaría de Rota & 662.553 & 31.938 \\
\hline $\begin{array}{l}\text { Capillas que sirven en monasterios de Se- } \\
\text { villa }\end{array}$ & 584.295 & 29.081 \\
\hline Capillas que sirven en hospitales de Sevilla & 584.295 & 29.081 \\
\hline Prior de Aroche & 497.368 & 26.368 \\
\hline Vicaría del Pedroso & 415.051 & 24.647 \\
\hline Vicaría de la Puebla del Guzmán & 821.807 & 22.990 \\
\hline Universidad de Sevilla & 431.131 & 22.849 \\
\hline Hospitales de Sevilla & 414.024 & 22.825 \\
\hline Capillas de Alcocer & 326.000 & 17.279 \\
\hline Vicaría de Cala & 325.658 & 17.253 \\
\hline Capilla de los Reyes & 288.678 & 15.297 \\
\hline Vicaría de Zalamea & 266.362 & 14.114 \\
\hline Curas del Sagrario & 1.604 .190 & 9.937 \\
\hline Prior de Algava & 180.802 & 9.583 \\
\hline Capilla Real de Granada & 172.799 & 9.159 \\
\hline Prior iglesia de Sevilla & 142.231 & 7.537 \\
\hline Capilla del Obispo de Escalas & 97.188 & 5.149 \\
\hline Abad de San Salvador & 94.404 & 5.004 \\
\hline
\end{tabular}




\begin{tabular}{|l|r|r|}
\hline \multicolumn{1}{|c|}{ CONTRIBUYENTE } & $\begin{array}{r}\text { VALOR RENTAS } \\
\text { ECLESIÁSTICAS }\end{array}$ & $\begin{array}{c}\text { CARGO } \\
\text { SUBSIDIO }\end{array}$ \\
\hline Vicaría de Villaverde y Umbrete & 75.828 & 4.017 \\
\hline Capilla de las Doncellas & 39.511 & 2.091 \\
\hline Capilla de Doña Elvira & 24.000 & 1.272 \\
\hline Cura de Santa María de los Ángeles & 11.000 & 583 \\
\hline Sacristán de Cardenal de Hostia & 8.000 & 424 \\
\hline $\begin{array}{l}\text { Sacristán de la Capilla del Arzobispo de } \\
\text { Toledo }\end{array}$ & 8.000 & 424 \\
\hline Cura de S. Bernardo & 22.000 & 110 \\
\hline Sacristanes del Altar Mayor & 129.036 & - \\
\hline Total & 249.922 .278 & 12.250 .755 \\
\hline
\end{tabular}

* Tanto de frailes como de monjas.

** Dado que los monasterios de monjas estaban exentos del pago del subsidio y excusado por merced regia, sus cantidades luego nunca se cobraban.

\section{BiBLIOGRAFÍA}

Aldea, Q. Diccionario de Historia Eclesiástica, Vol. II, Madrid, 1972.

Álvarez Vázquez, J. A. (1990), "La contribución de Subsidio y Excusado en Zamora (1500-1800)" en Fernández de Pinedo y Fernández, E. (Coord.), Haciendas forales y Hacienda Real. Homenaje a D. Miguel Artola y Felipe Ruiz Martín, II Encuentro de Historia económica regional, Vizcaya, pp. 123-137.

Álvarez Nogal, C. y Chamley, C. "La crisis financiera de Castilla en 1575-1577: fiscalidad y estrategia", Revista de Historia de la Economía y de la Empresa, VII, 2013.

Anes, R. (1996), Una contribución a la historia de la contabilidad: análisis de las prácticas contables desarrolladas por la tesorería de las Indias de Sevilla (1503-1717), Sevilla.

Carande Thovar (1949) Carlos Vy sus banqueros, Madrid.

Carlos Morales, C. J. de (1996) "Finanzas y relaciones clientelares en la Corte de Felipe II: Juan Fernández de Espinosa, banquero y ministro del rey", en Politica y religión en la Edad Moderna en España. Homenaje al profesor Pérez de Villanueva, Madrid, pp. 221-238.

Carlos Morales, C. J. de (1999) "La Hacienda Real de Castilla y la revolución financiera de los genoveses (1560-1575)", Chronica Nova, 26, pp. 37-78.

Carlos Morales, C. J. de: Martínez Millán, J (1991),“Los orígenes del Consejo de Cruzada (siglo XVI), Hispania, No 179, pp. 901-932. 
Carpintero Aguado, L. (1993), La congregación del clero de Castilla en el siglo XVII, Tesis doctoral inédita, leída en la Universidad Autónoma de Madrid, dir. Fernández Albaladejo.

Carpintero Aguado, L. (1989), "Iglesia y corte castellana en el siglo XVI: contribución y tributos", Hispania Sacra, № 41, pp. 547-567.

Carretero Zamora, J. M. y Galán Sánchez, Á (2013), “Las políticas del gasto: el servicio del reino, el crédito y la deuda en Castilla. De los Reyes Católicos a Carlos V", en Carretero Zamora, J. M. y Galán Sánchez, Á. (eds.), El alimento del Estado y la salud de la Res Publica: orígenes, estructura y desarrollo del gasto público en Europa, Madrid, pp. 473-500.

Carvajal de la Vega, D. (2011), "Redes socioeconómicas y mercaderes castellanos a fines de la Edad Media e inicios de la Moderna", en Carvajal de la Vega, D., Añíbarro Rodríguez, J. Vítores Casado, I. (Coord.) Redes sociales y económicas en el mundo bajomedieval, pp. 79-101.

Catalán Martínez, E. (1991), “La participación de la Iglesia en el pago de las deudas de la Corona, 1543-1746", en E. La Parra López y J. Pradells Nadal (Eds.) iglesia, sociedad y estado en España, Francia e Italia (ss. XVIII al XX), Alicante, pp. 41-58.

Catalán Martínez, E. (2013), De la décima al subsidio. Fiscalidad eclesiástica en la Diócesis de Calahorra y La Calzada", en Morelló Baget, J. (ed.) Financiar el reino terrenal. La contribución de la Iglesia a finales de la Edad Media (siglos XIII-XVI), Barcelona, 2013, pp. 345-377.

Cloulas, I. (1967) "Le subsidio de las galeras. Contribution du clergé espagnol a la guerre navale contre les infidèles de 1563 a 1574", Melanges de la Casa de Velázquez, $\mathrm{N}^{\circ} 3$, p. 289-326.

Dávila, M. D. (1971), "Política exterior del Rey Don Felipe III en Marruecos al iniciar su reinado". Boletín de la Institución Fernán González. $2^{\circ}$ sem., Año [50], n. 177, pp. 775-784.

Domínguez Ortiz, A. (1991) Orto y ocaso de Sevilla, Sevilla.

Drelichman, M. y Voth, H. J. (2010) "The sustanaible debts of Philippe II: a reconstruction of Castile's Fiscal Position, 1566-1596", The Journal of Economic History, Vol. 70.

Favier, J (1996), Les finances pontificales à l'époque du Gran Schime d'Occident (1378-1409), Bibliothèque des Écoles françaises d'Athènes et de Rome.

García Guerra, E. (2006), "Los bancos públicos en Madrid durante el reinado de Felipe II. Características, actividades y relaciones con las finanzas municipales", en Sanz Ayán, C. y García García B. J., Banca, crédito y capital. La monarquía hispánica y los antiguos Países Bajos, Madrid, pp. 299-328.

Giannini, M. C. (2003) L'e oro e la tiara. La costruzione dello spazio fiscale italiano della Santa Sede (1560-1620), Bolonia.

González Arce, J. D. (2010), "El consulado genovés de Sevilla (siglos XIII-XV). Aspectos jurisdiccionales, comerciales y fiscales", Studia Historica, N ${ }^{\circ} 28$, pp. 179-206. 
González Jiménez, M. (2009), "Propiedades, rentas y explotación del dominio del monasterio de San Isidoro del Campo", Historia. Instituciones. Documentos No: 36, pp. 199-227.

Goñi Gaztambide, J. G. (1958), Historia de la bula de Cruzada en España, Vitoria. Iturrioz Magaña, Á. (1987), Estudio del subsidio y excusado (1561-1808). Contribuciones económicas de la diócesis de Calahorra y La Calzada a la Real Hacienda, Logroño.

Kellenbez, H. (2000), Los Fugger en España y Portugal hasta 1560, Salamanca. Ladero Quesada, M. Á. (2009) La Hacienda Real de Castilla, Madrid.

Lorenzo Sanz, E. (1992) “Comercio de Castilla y León con América en el siglo XVI”, Jornadas sobre Zamora, su entorno y América, Zamora, pp. 421-440.

Lovet, A. W. (1982) “The general Settlement of 1577: An Aspect of Spanish Finance in the Early Modern Period", The Historical Journal, Vol. 25, No.1, pp. 1-22.

Lovet, A. W. (1980), “The Castillian Bankruptcy of 1575”, The Historical Journal, V. 23, No. 4.

Marchena Giménez, J. M. (2010) La vida y los hombres de la galeras de España (siglos XVI y XVII), Tesis doctoral dirigida por Dña. Magdalena de Pazzis Pi Corrales, Madrid.

Marcos Martín, A. (2013), "Porque el aprieto de mis armas y necesidad no da lugar a otra cosa... La primacía del gasto sobre el ingreso en la hacienda regia castellana de los siglos XVI y XVII", Carretero Zamora, J. M., y Galán Sánchez, Á. (eds.), El alimento del Estado y la salud de la Res Publica: orígenes, estructura y desarrollo del gasto público en Europa, Madrid, 2013, pp. 115-144.

Martín-Aceña, P. y Nogues-Marco, P. (2013), “Crisis bancarias en la historia de España. Del Antiguo Régimen a los orígenes del Capitalismo moderno”. en Comín, F. y Hernández, M. (eds.), Crisis económicas en España, 1300-2012. Lecciones de la Historia, Madrid, pp. 141-167.

Martín Prieto, P. (2013), "Formación y evolución del patrimonio del Monasterio de Santa Clara de Alcocer en la Edad Media”, Hispania Sacra, LXV, pp. 563-601.

Martínez Millán, J. y Trápaga Koldo, M. (2014), "La transformación institucional de la Cámara de la Casa Real de la Monarquía Hispana durante el siglo XVII", en Hortal Muñoz, J., Ladrador Arroyo, F. (dirs.), La casa de Borgoña: la casa del rey de España, Lovaina, pp. 317-360.

Menjot, D. y Sánchez Martínez, M (eds.) (2011), El dinero de Dios: Iglesia y fiscalidad en el Occidente medieval (siglos XIII-XV), Madrid.

Nieto Soria, J. M. (1993), Iglesia y génesis del Estado Moderno en Castilla (13691480), Madrid.

Nieto Soria, J. M. (1994), "El pontificado de Martín V y la ampliación de la soberanía real sobre la iglesia castellana (1417-1431)", En la España Medieval, $\mathrm{N}^{\mathrm{o}} 17$, pp. 113-132.

Nieto Soria, J. M. (1999), "Relaciones con el pontificado, Iglesia y poder real en Castilla en torno a 1500. Su proyección en los comienzos de reinado de Carlos I", Studia Historica. Historia Moderna. No 21, pp. 19-48. 
Ollero Pina, J. A. (2011), “La Iglesia de Sevilla y la consolidación de los subsidios (1482-1495), en D. Menjot y M. Sánchez Martínez (eds.) El dinero de Dios: Iglesia y fiscalidad en el Occidente medieval (siglos XIII-XV), Madrid, pp. 115-131

Perrone, S. T. (2008) Charles $V$ and the Castillian Assembly of the Clergy: negotiations for the ecclesiastical subsidy, Leiden.

Prodi, P. (2011), El soberano pontífice. Un cuerpo y dos almas: la monarquía papal en la primera Edad Moderna, Madrid.

Ruiz Martín, F. (1965), Lettres marchandes échangées entre Florence et Medina del Campo, París.

Ruiz Martín, F. (1990), Pequeño Capitalismo, gran capitalismo. Simón Ruiz y sus negocios en Florencia, Barcelona.

Tarsicio de Azcona (1983), "Estado e Iglesia en España a la luz de las Asambleas del clero en el siglo XVI", Actas del Congreso Internacional Teresiano, Salamanca, pp. 297-330.

Sanz Ayán, C. (2015), Un banquero en el Siglo de Oro. Octavio Centurión, el financiero de los Austrias, Madrid.

Ulloa, M. (1986), La Hacienda Real de Castilla en el reinado de Felipe II, Madrid.

Villaroel González, Ó. (2013), "La tributación de los eclesiásticos castellanos en el siglo XV: entre el Rey y el Papa", en J. Morelló i Baget (Coord.) Financiar el reino terrenal: la contribución de la Iglesia a finales de la Edad Media (siglos XIII-XVI), Barcelona, pp. 315-343.

Visceglia, M. A. (2004), “Convergencias y conflictos. La monarquía católica y la Santa Sede (siglos XVI-XVIII), Studia Historica. Historia Moderna, No 26, pp. 155-190. 